\title{
Preservatives and neutralizing substances in milk: analytical sensitivity of official specific and nonspecific tests, microbial inhibition effect, and residue persistence in milk
}

\author{
Sustâncias conservantes e neutralizantes no leite: sensibilidade analítica das provas oficiais \\ específicas, provas inespecíficas, inibição microbiana e persistência de resíduos no leite
}

\author{
Livia Cavaletti Corrêa da Silva ${ }^{I^{*}}$ Ronaldo Tamanini ${ }^{\mathrm{I}}$ Juliana Ramos Pereira ${ }^{\mathrm{II}}$ \\ Edson Antônio Rios ${ }^{\text {II }}$ José Carlos Ribeiro Junior ${ }^{I I}$ Vanerli Beloti ${ }^{I}$
}

\section{ABSTRACT}

Milk fraud has been a recurring problem in Brazil; thus, it is important to know the effect of most frequently used preservatives and neutralizing substances as well as the detection capability of official tests. The objective of this study was to evaluate the analytical sensitivity of legislation-described tests and nonspecific microbial inhibition tests, and to investigate the effect of such substances on microbial growth inhibition and the persistence of detectable residues after 24/48h of refrigeration. Batches of raw milk, free from any contaminant, were divided into aliquots and mixed with different concentrations of formaldehyde, hydrogen peroxide, sodium hypochlorite, chlorine, chlorinated alkaline detergent, or sodium hydroxide. The analytical sensitivity of the official tests was $0.005 \%, 0.003 \%$, and $0.013 \%$ for formaldehyde, hydrogen peroxide, and hypochlorite, respectively. Chlorine and chlorinated alkaline detergent were not detected by regulatory tests. In the tests for neutralizing substances, sodium hydroxide could not be detected when acidity was accurately neutralized. The yogurt culture test gave results similar to those obtained by official tests for the detection of specific substances. Concentrations of $0.05 \%$ of formaldehyde, $0.003 \%$ of hydrogen peroxide and $0.013 \%$ of sodium hypochlorite significantly reduced $(P<0.05)$ the microbial counts in milk after 24 and $48 \mathrm{~h}$ refrigeration. Formaldehyde and sodium hypochlorite remained detectable in milk after 48 and $24 \mathrm{~h}$ of refrigeration, respectively; while hydrogen peroxide could not be detected after 24h. Official tests for the detection of milk fraud by the addition of preservatives and neutralizing substances present limitations and may be ineffective in detecting milk adulteration.

Key words: fraud, formaldehyde, hydrogen peroxide, chlorinated compounds, inhibitors.

\section{RESUMO}

Fraudes no leite têm sido um problema recorrente no Brasil, tornando importante conhecer o efeito dos conservantes e neutralizantes utilizados com maior frequência, e a capacidade de detecção das provas oficiais. O objetivo deste trabalho foi avaliar a sensibilidade analítica de provas descritas pela legislação, das provas por inibição microbiana inespecífica, o efeito dessas substâncias na inibição do crescimento microbiano e a persistência de resíduos detectáveis após 48 horas de refrigeração. Lotes de leite cru, livres de sustâncias adulterantes, foram aliquotados e adicionados de diferentes concentrações de formaldeído, peróxido de hidrogênio, hipoclorito de sódio, cloro, detergente alcalino clorado e hidróxido de sódio. A sensibilidade analítica das provas oficiais foi: 0,005\% para formaldeido; 0,003\% para peróxido de hidrogênio e 0,013\% para hipoclorito. Cloro e detergente alcalino clorado não foram detectados pelas provas oficiais. A prova de neutralizantes não detectou hidróxido de sódio quando a acidez foi neutralizada com precisão. A prova da cultura de iogurte apresentou resultados próximos ao das provas oficiais para substâncias especificas. Concentrações de $0,05 \%$ formaldeido, 0,003\% de peróxido de hidrogênio e 0,013\% de hipoclorito de sódio reduziram significativamente $(P<0,05)$ a microbiota do leite após 24 e 48 horas de refrigeração. O formaldeido e hipoclorito de sódio permaneceram detectável no leite após 48 e 24 horas de refrigeração, respectivamente e o peróxido de hidrogênio não foi detectável após 24 horas. As provas oficiais para a pesquisa de fraudes por adição de conservantes e neutralizantes ao leite apresentam limitações e podem não ser capazes de detectar adulterações no leite.

Palavras-chave: fraude, formol, peróxido de hidrogênio, compostos clorados, inibidores.

\section{INTRODUCTION}

In the period between 1980 and 2010, milk was recognized as one of the most frequently defrauded foods in the world (MOORE et al., 2012). In Brazil, particularly, there have been recurrent

\footnotetext{
'Departamento de Medicina Veterinária Preventiva, Universidade Estadual de Londrina (UEL), Rodovia Celso Garcia Cid, PR 445, Km 380, Campus Universitário, 86951-990, Londrina, PR, Brasil. E-mail: liviacavaletti@gmail.com. *Corresponding author.

"Programa de Pós-graduação em Ciência Animal, UEL, Londrina, PR, Brasil.
} 
episodes of milk adulteration $(\mathrm{G} 1,2014)$. The most commonly observed fraud involves the addition of water associated to density restoratives or cheese whey to increase volume; neutralizing substances such as sodium bicarbonate and sodium hydroxide to mask the acidity caused by microorganisms; and preservatives such as hypochlorite, chlorine, hydrogen peroxide, formaldehyde, and bactericides or bacteriostatic substances to control microorganism growth and prolong product shelf life (KARTHEEK et al., 2011).

Preservatives and neutralizing substances in milk are prohibited by legislation (BRASIL, 2011) and may pose a risk to consumer health (ANVISA, 2007; EPA, 2000; NCI, 2011). In addition to the financial motivation, the difficulty in fraud detection only through routine testing incites milk-defrauding practices (KARTHEEK et al., 2011). Obtaining official evidence can be very demanding. Despite these hurdles, several researchers have succeeded in detecting preservatives and neutralizing substances in milk (FREITAS FILHO et al, 2009; FIRMINO et al, 2010; ROSA CAMPOS et al., 2011; SILVA et al., 2011; SOUZA et al., 2011).

The addition of preservatives and neutralizing substances in milk does not lead to significant changes in routine tests of physicochemical parameters, such as freezing point and density. Therefore, the legislation describes specific qualitative tests for the detection of these substances (BRASIL, 2006). However, data on the analytical sensitivity of these tests in detecting preservatives and neutralizing substances in milk samples, as well as the degradation of these adulterants in refrigerated milk are practically non-existent.

Given this background, the objective of the present study was to evaluate the analytical sensitivity of official tests specific to the detection of preservatives and acidity neutralizers experimentally added to milk, and to verify the capacity of nonspecific tests in evaluating preservative-promoted microbial growth inhibition. Experiments were further performed to determine the effect of adding these substances on microbial population counts and the persistence of detectable residues in milk after $24 / 48 \mathrm{~h}$ of refrigeration.

\section{MATERIALS AND METHODS}

a) Evaluation of the analytical sensitivity of tests for the detection of preservatives and neutralizing substances Three lots of refrigerated raw milk were $(6 \mathrm{~L}$ each) aseptically collected directly from the expansion tank of a dairy property of the Londrina municipality, in Paraná state, Brazil. Lots were collected on different days and transported to the laboratory in an isothermal box. Each lot had been previously assessed for all adulterant substances as prescribed by the Normative Instruction 68/MAPA (BRASIL, 2006) and were considered free of tampering. Each batch was split into 19 300-mL aliquots, 18 intended for the experimental addition of preservatives and neutralizers to milk and one for the negative control. Each aliquot received only one of the adulterants in one of the following concentrations: $0.0005 \%, 0.005 \%, 0.01 \%, 0.05 \%, 0.1 \%$, and $0.5 \%$ formaldehyde P.A.; $0.05 \%, 0.1 \%$, and $0.5 \%$ of $3 \%$ hydrogen peroxide (corresponding to $0.0015 \%$, $0.003 \%$, and $0.015 \%$ final concentration in milk, respectively); $0.05 \%, 0.1 \%$, and $0.5 \%$ of $2.5 \%$ sodium hypochlorite (corresponding to $0.0013 \%, 0.0025 \%$, and $0.013 \%$ final concentration in milk, respectively); $0.05 \%, 0.1 \%$, and $0.5 \%$ chlorine solution or chlorinated alkaline detergent (750ppm); and 0.01\%, $0.025 \%$, and $0.05 \%$ sodium hydroxide flakes $(100 \%)$.

With the exception of formaldehyde $\left(\right.$ Synth $^{\circledR}$, Brazil), all preservatives and neutralizing substances used in this study were purchased in market, and concentrations were selected based on the ones found in fraud reports and also in lower concentrations to determine analytical sensitivity. Three independent repetitions were performed, and each batch was analyzed in triplicate.

The prepared aliquots were analyzed for the presence of formaldehyde and hydrogen peroxide by the guaiacol method; chlorine, hypochlorite, and neutralizers using rosolic acid (method A) and phenolphthalein (method B); Dornic acidity and alizarol $(72 \% \mathrm{v} / \mathrm{v})$ stability tests were also performed as described by Normative Instruction 68/MAPA (BRASIL, 2006). The aliquots were also assessed by nonspecific tests for microbial inhibition: lacto-fermentation was performed as described by BEHMER (1999) with changes in incubation carried out at $36 \pm 1^{\circ} \mathrm{C}$ for $24 \mathrm{~h}$. The absence of clot formation was interpreted as positive for the presence of inhibitors and clot formation as negative. The yogurt culture test was performed as described by TRONCO (2008) and the Charm ${ }^{\circledR}$ CowSide II test Kit (Charm Sciences, Inc.) was performed according to the manufacturer's instructions.

b) Effect of the addition of preservatives and neutralizers on microorganisms in raw milk and the persistence of adulterants during refrigeration

Seven 400-ml aliquots of raw milk previously poured into sterile glass bottles were added 
with one of the following substances, in concentrations commonly used in fraud: $0.05 \%$ of formaldehyde P.A., $0.1 \%$ of $3 \%$ hydrogen peroxide $(0.003 \%$ final concentration in milk), $0.5 \%$ of commercial sodium hypochlorite solution $(0.013 \%$ final concentration in milk), $0.5 \%$ of $750 \mathrm{ppm}$ chlorine solution, $0.5 \%$ chlorinated alkaline detergent solution, or $0.1 \%$ sodium hydroxide flakes. One aliquot was used as the negative control. The mesophilic aerobic counts of the prepared aliquots were measured after 24 and $48 \mathrm{~h}$ of refrigeration in Petrifilm ${ }^{\mathrm{TM}}$ AC plates (3M, St. Paul, MN, USA), according to the manufacturer's instructions. A fraction of each aliquot was used to evaluate the persistence of these additive substances at three different times. Immediately after their addition to milk, and 24 and $48 \mathrm{~h}$ after refrigeration, using the methodology described in BRASIL (2006). These time periods were selected based on IN 62/ MAPA (BRASIL, 2011), which states that the time between milking and collection of raw milk at the dairy should not exceed $48 \mathrm{~h}$. Three independent repetitions were performed.

c) Detection of neutralizers in experimentally acidified milk

In another experiment, it was evaluated, with three independent repetitions, the interference of milk acidification in the detection of neutralizing substances. For each repetition, 1.8L of pasteurized milk, abiding legal parameters and adulterant-free, was homogenized and divided into six $300-\mathrm{mL}$ aliquots. Different concentrations of sodium hydroxide $(0.05$, $0.1,0.25,0.5$, and $1 \%$ ) were separately added to five of the aliquots, and one aliquot was assigned as the negative control. In addition to neutralizers detection using phenolphthalein (method B; BRASIL, 2006), the aliquots were evaluated for Dornic acidity, alizarol stability $(72 \% \mathrm{v} / \mathrm{v})$ (BRASIL, 2006), and pH (HI 8424, Hanna $\left.{ }^{\circledR}\right)$. These measurements were conducted in triplicate for each aliquot.

After the initial addition of sodium hydroxide and analysis as described above, to simulate milk acidification promoted by the microbial metabolism, $100 \mathrm{ml}$ of each aliquot was titrated with lactic acid P.A. using phenolphthalein as an indicator until its neutralization. This process is an inverse of the Dornic acidity test. After this procedure, analyses were repeated to verify if it is still possible to detect the added alkaline substance after an accurate neutralization.

To analyze the significance of the results and their variations by the addition of preservatives and neutralizers, statistical analysis was performed with the Microsoft Excel ${ }^{\circledR} 2010$ software using the student's t-test. In order to do so, the obtained counts values were converted into logarithms.

\section{RESULTS AND DISCUSSION}

After the experimental addition of preservatives and neutralizers to milk, the minimum final concentrations detected in milk, by the legislationdescribed specific tests (BRASIL, 2006), were 0.005\% for formaldehyde, $0.003 \%$ for hydrogen peroxide, $0.013 \%$ for sodium hypochlorite, and $0.1 \%$ for sodium hydroxide. At the concentrations evaluated in this study, chlorine and chlorinated alkaline detergent additives were not detected in any of the tests applied.

This study prioritized the evaluation of preservatives and neutralizers at concentrations commercially available. Hydrogen peroxide and sodium hypochlorite were added at initial concentrations of 3\% and $2.5 \%$, respectively, while their final concentrations detectable in milk were $0.003 \%$ and $0.013 \%$, respectively.

The test for formaldehyde detection showed greater analytical sensitivity but was extremely laborious, taking on average $1 \mathrm{~h}$ for each analysis. The formaldehyde was also detected by the microbial inhibition tests (Table 1) and caused a significant reduction $(\mathrm{P}<0.05)$ in the mesophilic aerobic count in raw milk; formaldehyde was the most powerful antimicrobial substance among those tested (Table 2).

On evaluating the persistence of formaldehyde residues during refrigeration, formaldehyde was detected after $48 \mathrm{~h}$ at a concentration of $0.05 \%$ (Table 2). Because formaldehyde concentrations tested were relatively high, it promoted a significant increase $(\mathrm{P}<0.05)$ in the Dornic acidity, from $17^{\circ} \mathrm{D}$ in the negative control to $20^{\circ} \mathrm{D}, 21^{\circ} \mathrm{D}$, and $28^{\circ} \mathrm{D}$, respectively for $0.05 \%, 0.1 \%$, and $0.5 \%$ of formaldehyde P.A. in the experimental aliquots. The detection of the fraudulent addition of formaldehyde is extremely important since it is a carcinogen even at low concentrations (NCI, 2011).

Regarding hydrogen peroxide detection, $0.05 \%$ of the commercial solution, corresponding to a final concentration of $0.0015 \%$ in milk and comparable to quantities used in fraud (SAHA et al., 2003; ANVISA, 2000), was not detected by the tests used. Furthermore, $0.1 \%$ of the commercial solution (final concentration $0.003 \%$ in milk) was detected immediately upon addition using the legally approved tests; however, it could not be detected after $24 \mathrm{~h}$ of refrigeration (Table 2), indicating rapid degradation of this substance, which would hinder its detection by industry or regulatory agencies. Although not detectable, this concentration of hydrogen peroxide caused a significant reduction $(\mathrm{P}<0.05)$ of microbes after 24 and $48 \mathrm{~h}$ of refrigeration (Table 2). The addition of hydrogen peroxide at any concentration did not cause any detectable changes in the physicochemical tests. 
Table 1 - Detection capacity for milk preservative and neutralizing substances by the yogurt culture (YC) test, lacto-fermentation (LF) test, Charm ${ }^{\circledR}$ CowSide II test (CT), and legislation standard (LG) tests.

\begin{tabular}{|c|c|c|c|c|c|c|}
\hline Evaluated Substance & Conc. ${ }^{1} \%$ & $\mathrm{YC}$ & $\mathrm{LF}^{2}$ & CT & $\mathrm{LG}^{3}$ & Detection Method $^{3}$ \\
\hline \multirow{3}{*}{ Formaldehyde } & 0.05 & + & + & + & + & \multirow{3}{*}{ Detection of formaldehyde } \\
\hline & 0.1 & + & + & + & + & \\
\hline & 0.5 & + & + & + & + & \\
\hline \multirow{3}{*}{ Hydrogen peroxide } & 0.05 & - & - & - & - & \multirow{3}{*}{ Detection of hydrogen peroxide (method B) } \\
\hline & 0.1 & - & - & - & + & \\
\hline & 0.5 & + & + & - & + & \\
\hline \multirow{3}{*}{ Sodium hypochlorite } & 0.05 & - & - & - & - & \multirow{3}{*}{ Detection of sodium hypochlorite } \\
\hline & 0.1 & - & - & - & - & \\
\hline & 0.5 & + & - & - & + & \\
\hline \multirow{3}{*}{ 750ppm Chlorine solution } & 0.05 & - & - & - & - & \multirow{3}{*}{ Detection of chlorine and hypochlorite } \\
\hline & 0.1 & - & - & - & - & \\
\hline & 0.5 & - & - & - & - & \\
\hline \multirow{3}{*}{ Chlorinated alkaline detergent } & 0.05 & - & - & - & - & \multirow{3}{*}{$\begin{array}{l}\text { Detection of chlorine, hypochlorite and } \\
\text { neutralizers (methods A and B) }\end{array}$} \\
\hline & 0.1 & - & - & - & - & \\
\hline & 0.5 & - & - & - & - & \\
\hline \multirow{3}{*}{ Sodium hydroxide } & 0.01 & - & - & - & - & \multirow{3}{*}{ Detection of neutralizers (methods A and B) } \\
\hline & 0.025 & + & - & - & - & \\
\hline & 0.05 & + & - & - & - & \\
\hline
\end{tabular}

${ }^{1}$ Concentration (v/v, except for Sodium hydroxide $\left.\mathrm{m} / \mathrm{v}\right) ;{ }^{2}$ It was considered that LF was able to detect inhibition of microbial growth when no clot was formed; ${ }^{3}$ According to Normative Instruction 68 (BRASIL, 2006).

Chlorine and chlorinated alkaline detergent residues were not detected by the legislation-described specific tests or by inhibition of microbial growth (Table 1) and did not cause significant reduction in the aerobic mesophilic counts of raw milk $(\mathrm{P}>0.05)$ (Table 2). Although they are classified as broad-spectrum antimicrobial reagents, chlorinated compounds are very susceptible to inactivation by organic matter (CORDS et al.,
2001). This explains the difficulty of its detection by the official method, which requires the presence of free chlorine (BRASIL, 2006).

For sodium hypochlorite, $0.5 \%$ of the commercial solution (final concentration 0.013\% in milk) was detected by the official test (BRASIL, 2006) and the yogurt culture test (Table 1), and was shown to promote significant $(\mathrm{P}<0.05)$ reductions in the microbial aerobic mesophilic counts of raw

Table 2 - Average inhibitory effect observed in mesophilic aerobic counts by preservatives and neutralizing substances experimentally added to raw milk after 24 and $48 \mathrm{~h}$ of refrigeration and persistence $(\mathrm{P})$ of these residues during refrigeration.

\begin{tabular}{lcccccccc}
\hline Treatment & $\mathrm{C}^{1} \%$ & $\mathrm{P}^{2} \mathrm{~T}_{0}$ & $\begin{array}{c}\mathrm{T}_{24}(\log \\
\left.\mathrm{UFC} \mathrm{mL}{ }^{-1}\right)\end{array}$ & $\mathrm{P} \mathrm{T}_{24}$ & Red. $^{3} \% \mathrm{~T}_{24}$ & $\begin{array}{c}\mathrm{T}_{48}(\log \mathrm{UFC} \\
\left.\mathrm{mL}^{-1}\right)\end{array}$ & $\mathrm{P} \mathrm{T}_{48}$ & Red. \% $\mathrm{T}_{48}$ \\
\hline Negative control & - & - & $7.19^{\mathrm{a}}$ & - & - & $7.67^{\mathrm{a}}$ & - & - \\
Formaldehyde & 0.05 & + & $4.12^{\mathrm{b}}$ & + & 42.74 & $3.94^{\mathrm{b}}$ & + & 48.56 \\
Hydrogen Peroxide & 0.1 & + & $6.18^{\mathrm{c}}$ & - & 13.97 & $7.27^{\mathrm{c}}$ & - & 5.19 \\
Sodium Hypochlorite & 0.5 & + & $5.84^{\mathrm{c}}$ & + & 18.69 & $7.01^{\mathrm{c}}$ & - & 8.57 \\
Chlorine Solution & 0.5 & - & $7.09^{\mathrm{a}}$ & - & 1.40 & $7.74^{\mathrm{a}}$ & - & -0.94 \\
Chlorinated alkaline detergent & 0.5 & - & $6.95^{\mathrm{a}}$ & - & 3.33 & $7.62^{\mathrm{a}}$ & - & 0.62 \\
Sodium Hydroxide & 0.1 & + & $7.11^{\mathrm{a}}$ & + & 1.06 & $7.23^{\mathrm{c}}$ & + & 5.75 \\
\hline
\end{tabular}

Values followed by the same letter in the same column are not different by student's t-test at $5 \%$ probability; ${ }^{1} \mathrm{C}=$ concentration evaluated; ${ }^{2} \mathrm{P}=$ persistence evaluated by detection of each substance (BRASIL, 2006); ${ }^{3}$ Red. $=$ percent of reduction. 
milk, which are detectable $24 \mathrm{~h}$ after its addition, but not after $48 \mathrm{~h}$ (Table 2). Lower concentrations were not detected in any of the tests used and none of the tested sodium hypochlorite concentrations caused any detectable changes in the physicochemical tests.

Addition of $0.01 \%, 0.025 \%$, and $0.05 \%$ sodium hydroxide solutions decreased $(\mathrm{P}<0.05)$ the obtained mean values of Dornic acidity, from $17^{\circ} \mathrm{D}$ in the negative control to $16^{\circ} \mathrm{D}, 13^{\circ} \mathrm{D}$, and $10^{\circ} \mathrm{D}$, respectively in the experimental aliquots. The $0.025 \%$ and $0.05 \%$ sodium hydroxide solutions also resulted in alkaline alizarol, although it was not detected by the neutralizers tests (methods A and B; BRASIL, 2006). The tests for the detection of neutralizers only detected the addition of $0.1 \%$ sodium hydroxide (Table 1), which is higher than the concentration reported in fraud, around $0.02 \%$ (ANVISA, 2007). Persistence in milk was observed for $0.1 \%$ sodium hydroxide after $48 \mathrm{~h}$ of refrigeration (Table 2 ).

As expected, the addition of sodium hydroxide had no significant effect on the reduction of aerobic mesophilic counts. Fraudulent addition of sodium hydroxide to milk is not intended to reduce microbial contamination but rather to mask its effect, as an increase in the Dornic acidity (TRONCO, 2008), since this method does not detect the actual concentration of lactic acid (MILAGRES, 2008).

In the yogurt culture test, $0.025 \%$ and $0.05 \%$ sodium hydroxide were detectable (Table 1 ), not by growth inhibition but due to enhanced violet color promoted at alkaline $\mathrm{pH}$. Still, yogurt test would indicate sample alteration. The $\mathrm{pH}$ change was also detected by the Dornic acidity and alizarol tests.
The presence of chlorinated alkaline detergent was not detected by any of the tests; neither by the chlorine detection tests nor by methods A and $\mathrm{B}$ for neutralizing substance detection. This may be because the detergent failed to cause any change in Dornic acidity $(\mathrm{P}>0.05)$.

Table 3 shows the results of the acidity neutralization detection testafter the addition of sodium hydroxide solutions at different concentrations and its neutralization with lactic acid. The milk acidification experiment was performed to assess the conditions under which this type of fraud is used. This experiment is the inverse of the adulteration technique, wherein a neutralizing substance is added to acidic milk.

The presence of lactic acid in plentiful amounts to neutralize sodium hydroxide prevented the detection of this neutralizing substance by the legislation-described test method (BRASIL, 2006). Despite reducing Dornic acidity, the addition of neutralizing substances is not always identified by this analysis, since equal amounts of neutralizing substances and lactic acid may result in milk with normal pH (MILAGRES, 2008). Chemically, the acid reacts with alkaline substances, resulting in water and salts. Thus, after the addition of lactic acid, sodium hydroxide could not be detected at any of the tested concentrations, indicating that when fraud is calculated for the accurate neutralization of lactic acid, sodium hydroxide is not detected. On the other hand, results of the alizarol test and Dornic acidity were good indicators for this adulteration, as these tests detected excess alkalizing agents (Table 3). This is may be due to differences in the sensitivity

Table 3 - Interference of experimental acidification of milk by lactic acid after addition of sodium hydroxide on the sensitivity of the analytical test for detecting neutralizing substances ${ }^{1}$ and changes observed in $\mathrm{pH}$, Dornic acidity $\left({ }^{\circ} \mathrm{D}\right)$, and alizarol $(72 \% \mathrm{v} / \mathrm{v})$.

\begin{tabular}{|c|c|c|c|c|}
\hline $\mathrm{NaOH}(\%)$ & Detection of neutralizing substances & $\mathrm{pH}$ & ${ }^{\circ} \mathrm{D}$ & Alizarol $72 \%$ \\
\hline 0 & - & 6.78 & 16 & stable \\
\hline 0.05 & - & 7.83 & 5 & stable/ alkaline \\
\hline 0.10 & + & 9.84 & WR & stable/ alkaline \\
\hline 0.25 & + & 11.65 & WR & stable/ alkaline \\
\hline 0.50 & + & 12.52 & WR & stable/ alkaline \\
\hline 1.00 & + & 13.25 & WR & stable/ alkaline \\
\hline 0 & - & 6.81 & 16 & stable \\
\hline 0.05 & - & 7.32 & 11.67 & stable/ alkaline \\
\hline 0.10 & - & 7.51 & 9.67 & stable/ alkaline \\
\hline 0.25 & - & 7.22 & 15.00 & stable \\
\hline 0.50 & - & 7.24 & 16.33 & unstable/ alkaline \\
\hline 1.00 & - & 6.75 & 27.67 & unstable/ acid \\
\hline
\end{tabular}

WR - without reading (persistent pink coloration appeared after addition of phenolphthalein); ${ }^{1}$ Detection of acidity neutralizers by method B - phenolphthalein (BRASIL, 2006). 
and specificity of the $\mathrm{pH}$ indicators used in these tests (alizarin and phenolphthalein, respectively).

At all concentrations of preservatives and neutralizing substances studied, milk remained stable to alizarol $(72 \% \mathrm{v} / \mathrm{v})$. The only change observed in this test was the alkalinization promoted by sodium hydroxide. The Charm ${ }^{\circledR}$ CowSide II test Kit, recommended for the detection of antibiotics in milk, only detected the addition of formaldehyde and did not suffer interference from the other substances assessed in this study.

\section{CONCLUSION}

The results indicate the limitations of the legally described tests in detecting the fraudulent addition of preservatives and neutralizers, besides difficulties in carrying out these tests, they may not be able to assure the absence of these substances in milk.

Specific tests for the detection of preservatives were not able to detect these substances in concentrations commonly used in fraud. Only the formaldehyde test showed high analytical sensitivity and was able to detect the tested concentrations.

Hydrogen peroxide detection was hindered due to the rapid degradation of the substance. The test for neutralizing substances was unable to detect sodium hydroxide in acidified milk, since there was no surplus of alkaline compounds after neutralization.

There is need for further studies on the development of more sensitive analytical methods and less laborious tests, thus ensuring their implementation in routine dairy activities for strengthening milk fraud control.

\section{REFERENCES}

ANVISA(AGÊNCIANACIONALDE VIGILÂNCIASANITÁRIA). Informe Técnico n.34, de 31 de outubro de 2007. Available from: $<\mathrm{http}$ ://s.anvisa.gov.br/wps/s/r/REL > . Accessed: Oct. 01, 2013.

BEHMER, M.L.A. Tecnologia do leite. 13.ed. São Paulo: Nobel, 1999. 320p.

BRASIL. Ministério da Agricultura, Pecuária e Abastecimento. Portaria n.166, de 5 de maio de 1998. Diário Oficial [da] República Federativa do Brasil, Brasília, seção 1, p.42, 6 maio 1998. Available from: <http://pesquisa.in.gov.br/imprensa/jsp/ visualiza/index.jsp?jornal $=1$ \&pagina $=58 \&$ data $=06 / 05 / 1998>$. Accessed: Sept. 15, 2013

BRASIL. Ministério da Agricultura, Pecuária e Abastecimento. Instrução Normativa n.68, de 12 de dezembro de 2006. Diário Oficial [da] República Federativa do Brasil, Brasília, seção 1, n.239, p.8, 14 dez. 2006. Available from: $<$ http://pesquisa.in.gov. $\mathrm{br} /$ imprensa/jsp/visualiza/index.jsp?jornal $=1 \&$ pagina $=8 \& \mathrm{da}$ ta $=14 / 12 / 2006>$. Accessed: Sept. 15, 2013.

BRASIL. Ministério da Agricultura, Pecuária e Abastecimento. Instrução Normativa n.62 de 29 de dezembro de 2011. Diário Oficial [da] República Federativa do Brasil, Brasília, seção 1, n.251, p.6, 30 dez. 2011. Available from: <http://pesquisa.in.gov. $\mathrm{br} / \mathrm{imprensa} / \mathrm{jsp} / \mathrm{visualiza} /$ index.jsp?jornal $=1 \&$ pagina $=6 \& \mathrm{da}$ ta $=30 / 12 / 2011>$. Accessed: Sept. 15, 2013.

CORDS, B.R. et al. Cleaning and sanitizing in milk production and processing. In: MARTH, E.H.; STEELE, J.L. Applied dairy microbiology. 2.ed. New York: Marcel Dekker, 2001. p.547-587.

EPA. United States Environmental Protection Agency. Chlorine: hazard summary. 2000. Available from: <http://www.epa.gov/ airtoxics/hlthef/chlorine.html>. Accessed: Dec. 04, 2012.

FIRMINO, F.C. et al. Detection of fraud in cooled raw milk of Rio Pomba, Minas Gerais. Revista do Instituto de Laticínios Cândido Tostes, v.65, n.376, p.5-11, 2010. Available from: $<$ http://www.revistadoilct.com.br/audiencia pdf.asp?aid2 $=402 \& n$ omeArquivo $=\mathrm{v} 65 n 376 a 01$. pdf. $>$. Accessed: Oct. 03, 2013.

FREITAS FILHO, J.R. et al. Physical-chemical and microbiological characterization of the milk in nature from informal commerce in the city of Garanhuns - PE. Revista Brasileira de Tecnologia Agroindustrial, v.03, n.02, p.38-46, 2009. Available from: $<$ http://revistas.utfpr.edu.br/pg/index.php/rbta/article/view/397>. Accessed: Oct. 02, 2013.

G1 RS MP deflagra sexta fase da Operação Leite Compensado no RS e PR. jun. 2014. Available from: <http://g1.globo.com/rs/ rio-grande-do-sul/campo-e-lavoura/noticia/2014/06/mp-deflagrasexta-fase-da-operacao-leite-compensado-no-rs-e-pr.html>. Accessed: Jun. 03, 2014

KARTHEEK, M.A. et al. Determination of adulterants in food: a review. Journal of Chemical and Pharmaceutical Research, v.3, n.2, p.629-636, 2011.

MILAGRES, M.P. Desenvolvimento de metodologia analítica para determinação da concentração real de ácido lático em leite por cromatografia líquida de alta eficiência - exclusão de íons. 2008. 75f. Dissertação (Mestrado em Ciência e Tecnologia de Alimentos) - Programa de pós-graduação em Ciência e Tecnologia de Alimentos, Universidade Federal de Viçosa, Viçosa-MG.

MOORE, J.C. et al. Development and application of a database of food ingredient fraud and economically motivated adulteration from 1980 to 2010. Journal of Food Science, v.77, n.4, p.118-126, 2012.

NCI (NATIONAL CANCER INSTITUTE). United States of America. Formaldehyde and cancer risk, 2011. Available from: $<$ http://www.cancer. gov/cancertopics/factsheet/Risk/formaldehyde-r2>. Accessed: Nov. 04, 2013.

ROSA-CAMPOS, A.A. et al. Physical-chemical evaluations and research fraud in integral pasteurized type $\mathrm{C}$ produced in Brasília, Federal District. Revista do Instituto de Laticínios Cândido Tostes, v.66, n.379, p.30-34, 2011. Available from: <http://www.revistadoilct. com.br/detalhe_artigo.asp?id=425>. Accessed: Oct. 06, 2013.

SAHA, B.K. et al. Study on the preservation of raw milk with hydrogen peroxide $\left(\mathrm{H}_{2} \mathrm{O}_{2}\right)$ for rural dairy farmers. Pakistan Journal of Nutrition, v.1, n.2, p.36-42, 2003. Available from: $<$ http://www.scialert.net/qredirect.php?doi=pjn.2003.36.42\&linki d=pdf $>$. Accessed: Oct. 17, 2013. doi: 10.3923/pjn.2003.36.42.

SOUZA, S.S. et al. Monitoring the authenticity of Brazilian UHT milk: a chemometric approach. Food Chemistry, v.124, p.692-695, 2011. Available from: <http://www.sciencedirect.com/ science/article/pii/S0308814610007855>. Accessed: Oct. 17, 2013. doi: http://dx.doi.org/10.1016/j.foodchem.2010.06.074.

TRONCO, V.M. Manual para inspeção da qualidade do leite. 3ed. Santa Maria: UFSM, 2008. 206p. 